\title{
Government, business and NPOs: formation of a new model of interaction and assessment of its effectiveness
}

\author{
Alla Aleksandrovna Bylinskaya, and Sergey Aleksandrovich Sudin \\ Lobachevsky State University of Nizhni Novgorod, 23, Gagarin avenue, Nizhni Novgorod, Russia
}

\begin{abstract}
The relevance of the research topic is due to the denationalization of the social services market and, as a result, the growing importance of the third sector in their provision; the development of civil society, the construction of social problems, in the solution of which nonprofit organizations play an important role. A comparative analysis of assessments of the emerging model of interaction between civil society and the state will allow us to determine its current state, show strengths and weaknesses, the most pressing problems and development trends. A large role in the study of the issues raised belongs to the study and critical understanding of the leading practices of building interaction between the state and civil society, which will not only adapt the most appropriate practices, but also avoid possible problems. The proposed research will help to establish feedback between the state, business and supported NPOs and develop recommendations for optimizing this interaction. The aim of the study is to comprehensively evaluate the effectiveness of the emerging model of interaction between the state and NPOs as new actors in the country's economic and socio-cultural policy and forecast the prospects for its development. The study is based on the study of the perceptions of leaders and key actors of NPOs about the prospects for the development of their organizations in the context of the emerging model of interaction with business and the state. The authors put forward a hypothesis about the need to study the assessments of the existing model of interaction between the state and NPOs by representatives of executive authorities responsible for the implementation of relevant programs, direct managers and key actors of NPOs, as well as representatives of target groups of their activities in the regions to determine the problems and prospects of interaction between the state, business and NPOs.
\end{abstract}

\section{Introduction}

The transition to the polysubject market of social services, initiated by 442-Ф3 "On the Basics of Social Services for Citizens of the Russian Federation", put an end to the state monopoly on their provision and led to the emergence of not only registers of social service providers, but also numerous socially oriented NPOs that spread their activity in all kinds of areas of social support and assistance. The social construction of problems, attention to the needs of deprived social groups, the implementation of the principle "nothing for us without us" when planning measures for their social protection has become a positive example of 
adapting international experience and increasing trust in non-state actors of social protection and assistance. This policy also became a response to the de facto ban on financing of civic activism of social orientation by foreign funds, which for a long time provided the opportunity for systematic work for leaders of the main areas of activity. Over the three years that have passed since the launch of the grant distribution system in its modern form, there has been a need for its assessment both on the part of NPOs, participating or not participating in the application process and implementation of initiatives, and on the part of government agencies. In 2016, under the direcrion of S.A. Sudin, a large research was carried out to study the interaction of NPOs and the state, during which problems were identified that hinder their constructive interaction: bureaucratization and control as a result of a lack of trust, strict regulation of the types of services, focus on image projects in the distribution of funds, high entry barriers for obtaining funding through the provision of services and many others. The system of presidential grants has become a fundamentally new step in supporting not only civil society as such, but also those social groups and individuals to whom its activity is directed. A comprehensive assessment of the effectiveness of socially oriented NPOs, an analysis of the range of thematic areas as an indicator of the most pressing social problems, as well as the prospects of the system itself is the subject of the proposed study.

\section{Materials and methods}

The research questions presented in this study are characterized by relative novelty and are being implemented within the framework of related thematic areas. First of all, NPOs and their activities are considered as a component of a civil society that is in the stage of formation and, therefore, experiencing specific difficulties associated with trust from state institutions, the formation of civic consciousness, stimulation of population activity, and the possibility of using foreign models of interaction.

The issues of the formation of civil society are in the focus of M.K. Gorshkov [1], [2], Z.T. Golenkova [3], I.A. Khalii [4]. The issues of forming interaction and monitoring the state of civil society are presented in the works of the staff of the Center for Civil Society Research and the Non-Profit Sector of the Higher School of Economics: L.I. Yakobson, I.V. Mersiyanova, V.B. Benevolensky, M.N. Gromova et al. [5], [6], [7], [8], [9]. Another area is the study of volunteering as a manifestation of civic engagement and the basis for the formation of non-profit structures. This aspect is at the center of research of the employees of the Ural Federal University. The first President of Russia B.N. Yeltsin: G.E. Zborovsky [10], [11], M.V. Pevnoi [12], A.A. Kuzminchuk [13].

The works of foreign authors reflect the issues of relationship in the development of civil society and the non-profit sector [14], cooperation between the state and the non-profit sector [15], the impact of democratization on the development of NPOs [16], network interaction of NPOs [17], financial management of NPOs and diversification of sources their income [18], the problem of changing the scale of the spread of NPOs and indicators of their development [19].

The scientific novelty of the research consists of the goal and objectives of the research and consists in an attempt to create a system for assessing state support for NPOs through grants, funding through the provision of services, as well as by comparing with the practices of international experience. The problem under study is to assess the effectiveness of the existing system of interaction between business, government and NPOs and compare with the results of the previous research. The social-constructionist approach presupposes the need for further construction of social problems in the sphere of NPO activity, the structural and functional one - a description of the place of NPOs in the civil society system and an analysis of their functions; systemic - analysis of the activities of NPOs in the 
system of social relations in the close relationship of structures, institutions and processes of modern Russia.

When performing the work, approaches and methods were used to solve theoretical and practical research problems. The theoretical basis will be made up of the system, structural and functional and problemological approaches taken together, which make it possible to form the conceptual apparatus of the research and interpret the basic concepts in a social and scientific context.

The following issues are used as empirical methods aimed at collecting and processing information:

1. In-depth interviews with the representatives of the executive authorities responsible for interaction with civil society institutions, leaders and key actors of NPOs, as well as representatives of target groups to which their activities are directed. The results of in-depth interviews will form the basis for the formation of tools for mass surveys.

2. Questionnaires allowing to give a quantitative and qualitative assessment of the effectiveness of NPOs from the point of view of their clients, to highlight the forms of their participation in the life of society. In addition to traditional technologies for collecting personal data, it is planned to use paperless technologies, which will facilitate the process of collecting data, increase the number of respondents to provide the highest quality content.

3 Content analysis of open sources devoted to the activity of NPOs, assessing their resource capacity and effectiveness in various areas of social functioning.

\section{Results and discussion}

The results of the research are consistent with the tasks. First of all, a quantitative and qualitative analysis of the existing thematic areas of activity of NPOs receiving support from the state was carried out. This is considered as one of the main indicators of the recognition of their relevance for the economic socio-cultural development of the country. The study of assessments of the existing model of interaction between the state and NPOs in the future will become a reliable feedback tool and provide valuable analytical material. In the course of the study, assessments were collected from employees of executive authorities, from leaders and key actors of NPOs, and from representatives of target groups to whom their activities are directed. The data obtained make it possible to assess in dynamics the effectiveness of public policy measures in relation to civil society based on a comparison of new data with the results of previous studies.

The cross-cultural nature of the study also involves the study of the latest trends in the dynamics of interaction between the state and civil society abroad, as well as a critical analysis of existing practices and an assessment of the prospects for their implementation in Russia.

The involvement of the leading actors of NPOs in the application system and the implementation of project initiatives contributes to the formation of not only assessments of the current state of the interaction system, but also scenarios for the further development of relations between the state and NPOs. Of particular interest for future research is the assessment of the prospects for the development of social entrepreneurship, which we understand as the next step in the formation and development of NPOs.

The research work was carried out in two main stages.

The first stage is theoretical and methodological one. At this stage, the development of the methodological base of the study was carried out, the analysis of the domestic and foreign discourse of the problems of interaction between civil society and the state, the existing socio-cultural context, the development and testing of research tools and the solution of organizational and technical issues was carried out. 
Within the framework of this stage, the following procedures have been implemented:

1. Development and approval of the theoretical basis of the study and its methodological foundations; preliminary analysis of the object, putting forward working hypotheses. In the course of implementing this step, a comprehensive research program was created and publications were prepared on the theoretical conceptualization and empirical operationalization of various models of interaction between the state and civil society institutions.

2. Conducting a series of pilot studies to test questionnaires, creating data entry matrices in SPSS. Data analysis and formulation of the final versions of the questionnaires. The result of this step is a data collection tool for all groups of respondents.

3. Preparation of publications on the theoretical part of the work. Within the framework of this stage, the publication of a collection of scientific works "Civil society in Russia: modern challenges" [20], including works on the problems of interaction between the state, business and civil society institutions, was carried out.

The second stage of the work is the empirical and analytical stage. Within the framework of this stage, the planned research procedures were implemented, the main array of data was obtained, their processing and meaningful analysis were carried out.

During the implementation of this stage:

1. A sample was formed for all groups of respondents.

2. Research has been carried out at all empirical sites. The bases of matrices in the sav format were formed, their processing and meaningful analysis were carried out. During the implementation of this stage, databases on questionnaires and protocols of in-depth interviews were obtained.

It is planned to build frequency and linear distributions by research parameters, cross tables, multivariate data analysis, identification of functional dependencies of research parameters, etc. preparation of publications based on the results of an empirical study of models of family practices in a civil society.

The implementation of the study made it possible to obtain the following results:

1. Development and approval of the theoretical basis of the study and its methodological foundations; preliminary analysis of the object, putting forward working hypotheses. During the implementation of this step, a comprehensive research program was created and publications were prepared on the theoretical conceptualization and empirical operationalization of various models of interaction between the state and civil society institutions.

2. A series of pilot studies have been carried out to test the questionnaires, create data entry matrices in SPSS. The analysis of the data and the formulation of the final versions of the questionnaires were carried out. The result of this step is the generated data collection toolkit for all groups of respondents.

S.A. Sudin conducted a study "The state as a partner of Russian NPOs", during which the heads and key actors of non-profit socio-medical organizations were interviewed by the method of expert interviews $(\mathrm{N}=47)$. As a result of the study carried out during the period of radical transformation of the model of interaction between NPOs and the state, the following problems were identified:

1. Lack of effective mechanisms of state subsidies for public organizations, implemented through contractual relations;

2. The actual lack of interest on the part of state authorities in enhancing interaction with public organizations;

3. Weak feedback mechanisms in the chain of interaction between the state and NPOs, which do not allow for a comprehensive assessment of the effectiveness of both the interaction itself and the activities of public organizations. A narrow range of indicators and 
data, represented by the data contained in the financial statements and indicators of the budgetary efficiency of NPOs.

As a result, since public authorities are not sufficiently well aware of the activities of public organizations, this does not contribute to increasing confidence and expanding the range of areas of interaction between the state and NPOs.

The transformation of state policy towards NPOs, expressed in the creation of registers of providers of social services and, later, the activation of grant programs, should have changed the attitude towards state policy in this area. A comprehensive assessment of the emerging system of interaction can become a source of important information for its further planning.

With the support of the ISEPI Foundation, the project "Research on partnership between civil society institutions, government and business for the development of dialogue, strengthening civil society and dissemination of best practices in this area" was implemented. The implementation of the project included a study of the main practices of social partnership and the identification of problems standing in the way of the development of social partnership. The study was conducted in Moscow, St. Petersburg, Nizhny Novgorod, Pskov, Samara regions and in the Perm Territory. An expert survey of 120 people (20 in each of the regions) was carried out, 6 focus groups were conducted, with a total of 62 participants. A total of 182 experts took part in the project. Table 1 presents data on the composition and structure of the expert group.

Table 1. Composition and structure of the expert group

\begin{tabular}{|c|c|c|c|c|c|c|}
\hline Region & $\begin{array}{c}\text { Men/ } \\
\text { women }\end{array}$ & $\begin{array}{c}\text { Government } \\
\text { departments } \\
\text { - }\end{array}$ & Business & NPOs & $\begin{array}{c}\text { Experts/ } \\
\text { universities }\end{array}$ & Media \\
\hline Moscow & $8 / 12$ & 4 & 5 & 11 & 0 & 0 \\
\hline $\begin{array}{c}\text { Saint- } \\
\text { Petersburg }\end{array}$ & $12 / 8$ & 4 & 5 & 7 & 4 & 0 \\
\hline $\begin{array}{c}\text { Nizhny } \\
\text { Novgorod }\end{array}$ & $13 / 7$ & 3 & 7 & 9 & 1 & 0 \\
\hline $\begin{array}{c}\text { Perm } \\
\text { region }\end{array}$ & $7 / 13$ & 4 & 6 & 7 & 2 & 1 \\
\hline Pskov & $13 / 7$ & 5 & 5 & 5 & 3 & 2 \\
\hline Samara & $7 / 13$ & 5 & 6 & 6 & 3 & 0 \\
\hline Total & $60 / 60$ & 25 & 34 & 45 & 13 & 3 \\
\hline
\end{tabular}

The age structure of the research participants includes respondents and experts aged 20 to 70 years, of which the age group 20-30 years old was 26 people, the group 31-40 years old was 31 people, the group 41-50 years old was 31 people, the group 51-60 years was 21 people, the group of 61-70 years was 5 people.

According to the results of the study, it was revealed that among the experts there is no unambiguous interpretation of both the very concept of "Social partnership" and the basic forms of its implementation.

Based on the results of the expert study, the basic forms of social partnership implementation include:

1. formation of collegial advisory bodies at the federal, regional and municipal levels, mainly in the form of public councils, in order to expand the possibilities of interaction between the state, business and NPOs and to provide conditions for the inclusion of business in solving issues of the development of public institutions;

2. financing of the activities of NPOs on a competitive basis, involving the participation of interested partners from both government bodies and business structures in order to increase the efficiency of allocation of both state and charitable funds and the effectiveness of joint projects; 
3. charity as the simplest and most important form of interaction between different sectors.

In accordance with the resource base, based on the results of the study, a number of forms of social partnership were named, such as the implementation of joint projects, volunteer actions, charitable actions, the provision of the infrastructure by the business for the implementation of projects within the framework of social partnership and material assistance provided by the business of the NPO.

According to the results of the study, it was found that grants are of particular importance for financing social partnership projects, according to experts. It is they who act as direct investments that provide both the solution of problems and stimulate the institutional development of social partnership. According to experts, the main questions that business and NPOs have to the authorities are related to the organization of effective interaction.

According to the results of the study, based on expert assessments, it was revealed as follows:

1. Lack of interest and initiative among officials responsible for the implementation of projects within the framework of social partnership. Since responsible officials are accountable to the state, they are unable to ensure effective representation of the interests of society. Thus, bridging the gap in the "power-society" chain becomes a big problem.

2. The existence of a demand for social partnership is a consequence of the insufficiently effective work of the state and social services.

3. The inertial nature of interaction between government and society. In most cases, interaction is carried out in the format of social protection that is familiar to everyone. Despite the fact that this form of interaction is passive and a transition to active forms of interaction in this area is required, the inertial effect is triggered and this transition does not occur.

4. Despite the awareness of the importance of moving away from the primitive distribution of funds to the unprotected strata of the population to the development of active forms of interaction with active strata of society interested in working on solving common problems, this problem has not yet been overcome.

In the course of the study, the main criteria and requirements for participants in social partnership were tested. The structure of the criteria is shown in Table 2.

Table 2. Criteria and requirements for partners

\begin{tabular}{|l|l|}
\hline Group of criteria & Components of the criteria group \\
\hline $\begin{array}{l}\text { Requirements for } \\
\text { the competences }\end{array}$ & $\begin{array}{l}\text { if potential partners have the necessary competencies } \\
\text { clarity and consistency in decision-making and interaction within the } \\
\text { framework of social partnership } \\
\text { diligence, punctuality and responsibility in relation to the undertaken } \\
\text { obligations } \\
\text { compliance with legal regulations, requirements and criteria }\end{array}$ \\
\hline $\begin{array}{l}\text { Moral and ethical } \\
\text { requirements }\end{array}$ & $\begin{array}{l}\text { honesty and decency } \\
\text { willingness to take the path of making reasonable compromise decisions } \\
\text { ability to suppress "corporate selfishness" } \\
\text { ban on solving your own/personal problems through a joint project } \\
\text { moral stability }\end{array}$ \\
\hline $\begin{array}{l}\text { Technological } \\
\text { requirements and } \\
\text { criteria }\end{array}$ & $\begin{array}{l}\text { effective financial control mechanisms } \\
\text { transparency environmental friendliness and respect for the environment } \\
\text { ability to implement the effective projects } \\
\text { activity and willingness to work together }\end{array}$ \\
\hline
\end{tabular}


Table 2. Continued

\begin{tabular}{|l|l|}
\hline $\begin{array}{l}\text { Communication } \\
\text { requirements }\end{array}$ & $\begin{array}{l}\text { trust in partners } \\
\text { mutual interest in potential participants in a joint project } \\
\text { ability to carry out the search for and finding compromise solutions and } \\
\text { desire }\end{array}$ \\
\hline $\begin{array}{l}\text { Image } \\
\text { criteria }\end{array}$ & $\begin{array}{l}\text { whether potential partners have a positive reputation, } \\
\text { whether potential participants in the interaction have the } \\
\text { recommendations, } \\
\text { negative attitude of participants towards corruption, rejection of } \\
\text { various corruption schemes } \\
\text { stable positions of potential partners in the market } \\
\text { whether potential partners have a portfolio of projects }\end{array}$ \\
\hline
\end{tabular}

According to the results of the study, the following were named as undesirable partners: illegal business, interaction with which was marked as inadmissible within the framework of social partnership, classifying it as criminal; types of industries whose products are capable of harming health; organizations engaged in political activities; organizations that appear on various lists of unfair partners.

On the basis of the study carried out by the authors, the key factors at various levels that hinder the implementation of social partnership in Russia were identified. The results are shown in Table 3.

Table 3. Factors hindering the implementation of social partnership

\begin{tabular}{|c|c|}
\hline Levels & Obstacles to the implementation of social partnership \\
\hline $\begin{array}{l}\text { Level of } \\
\text { organization }\end{array}$ & $\begin{array}{l}\text {-weak institutional support for the activities of NPOs, } \\
\text {-insufficiently clear understanding of the interests of partners, } \\
\text {-incompleteness of information about the activities of NPOs both from business and } \\
\text { from the state, } \\
\text { - unsatisfactory quality of management, } \\
\text { - lack of a clearly formulated mission of the NPOs }\end{array}$ \\
\hline Region level & $\begin{array}{l}\text {-indifferent attitude to serious problems, } \\
\text {-reduction of funding for NPOs' projects due to the crisis, } \\
\text {-low level of public solidarity, } \\
\text { - lack of formation and lack of consideration of public opinion in matters of social } \\
\text { partnership, } \\
\text { - business misunderstanding of the meaning of interaction with NPOs, } \\
\text { - rejection of business and NPOs by the state as equal partners, and unwillingness to } \\
\text { jointly solve common problems, } \\
\text { - lack of government interest in involving strong NPOs and businesses in solving } \\
\text { major social problems, } \\
\text { - administrative barriers and attempts at administrative pressure on both business } \\
\text { and non-profit organizations, } \\
\text { - lack of effective mechanisms for a reliable comprehensive assessment of the } \\
\text { professional activities of NPOs }\end{array}$ \\
\hline
\end{tabular}


Table 3. Continued

\begin{tabular}{|l|l|}
\hline \multirow{5}{*}{ National level } & - gaps in the regulatory framework governing the activities of NPOs, \\
- low efficiency of the state in terms of performing a number of functions, combined \\
with high bureaucratization and insufficient customer focus, \\
- lack of flexible forms of interaction, attempts to establish a rigid framework by the \\
state, lack of interest among the officials in working in social projects, \\
-administrative pressure from the state, expressed in attempts \\
to exclude business from the number of partners and organize work only with NPOs \\
within the framework of social partnership projects, \\
- lack of effective mechanisms for a reliable comprehensive assessment of the \\
professional activities of NPOs. \\
\end{tabular}

\section{Conclusions}

1. Prospects for the implementation of social partnership at the present stage are primarily associated with the need to create conditions conducive to increasing the interest of business in interaction with NPOs.

2. Strengthening of institutional support for the activities of NPOs is required.

3. Formation of civil society is possible only with the formation of effective mechanisms of social partnership, requiring the active participation of the nongovernmental sector in making managerial decisions.

4. Social partnership is a powerful stabilizer of not only the political, but also the socioeconomic situation in the country. As a powerful tool for supporting social innovation and civic initiatives, effective social partnership creates conditions for stability in the future.

5. The current stage is characterized not only by an increase in the understanding of the very idea of social responsibility and interest in the topic of social partnership, but also by the intensification of involvement in social projects, especially among young people. In Russia, there is a gradual departure from social support and a transition to social partnership. A kind of new "trend" is the intensification of partnership interaction between business, the state and NPOs, the involvement of various structures in projects.

5. To increase the efficiency of social partnership, it is necessary to solve the problem of expanding to increase the motivated circle of participants in the process of partnership interaction by creating appropriate motivational mechanisms. In this regard, the questions of search, support for leadership, and education of leaders acquire particular relevance. It also forms new development tracks, as to become a leader is not only fashionable, but interesting as well. Thus, new horizons for development, both personal and eventually federal, are opening up.

5. Today, work is needed in a number of areas to solve the problem of enhancing interaction between the state, business and NPOs through social partnership. The main tasks to be solved:

-creation of favorable conditions for business development;

- creation of effective mechanisms to promote the development of small business as a potential subject of state orders by increasing the competence and professionalism of this participant in social partnership projects;

-expansion of the range of areas of work of the main sites providing interaction between the state, business and NPOs;

-increasing transparency and accountability in the implementation of grants; 
- solving the problems of popularizing social partnership, its informational support, the formation of management skills in the non-state sector and fundraising;

- creation of a system for training leaders, which provides an effective mechanism for involving children and youth in social partnership.

\section{References}

1. Mikhail K. Gorshkov, Sociological studies, 12 (2016)

2. Mikhail K. Gorshkov, Sociological studies, 1 (2017)

3. Z.T. Golenkova, Sociological studies, 3 (1997)

4. I.A Khaliy, Polis. Political research, 3 (2012)

5. Irina V. Mersianova, Vladimir B. Benevolenski, Public Administration Issues, 4 (2016)

6. V.B. Benevolensky, Civil Society in Russia and Abroad, 1 (2015)

7. I.V. Mersiyanova, I.E. Korneeva, Monitoring Public Opinion: Economic and Social Change, 2 (2017)

8. Irina V. Mersianova, Vladimir B. Benevolenski, Public Administration Issues, 2 (2017)

9. M.N. Gromova, I.V. Mersiyanova, Civil Society in Russia and Abroad, 1 (2016)

10. G.E. Zborovsky, Bulletin of the Perm National Research Polytechnic University, Socio-economic sciences, 3 (2017)

11. G.E. Zborovsky, M.V. Pevnaya, A.A. Vedernikov, Bulletin of the Perm National Research Polytechnic University. Socio-economic sciences, 4 (2018)

12. M.V. Pevnaya Volunteering Management: International Experience and Local Practices (2016)

13. A.A. Kuzminchuk, M.V. Pevnaya, E.R. Timirshina, Bulletin of the Surgut State Pedagogical University, 2 (2018)

14. J. Casey, The Nonprofit World: Civil Society and the Rise of the Nonprofit Sector, (2015)

15. L.M. Salamon, S. Toepler, Journal of Voluntary and Nonprofit Organizations, 6 (2015)

16. S. Appe, Voluntas, 1 (2016)

17. T. Brandsen, M. Oude Vrielink, T. Schillemans, E. Van Hout, Nonprofit Organisations, Democratisation and New Forms of Accountability: A Preliminary Evaluation. In A. Ball\& Osborne (Eds.), Social Accounting and Public Management London: Routledge, (2011)

18. J. Lu, J Shon, P. Zhang, Nonprofit \& voluntary sector quarterly, 1 (2020)

19. A. Pennerstorfer, A.C. Rutherford, Nonprofit \& voluntary sector quarterly, 2 (2019)

20. Civil Society in Russia: Challenges of the Modernity, Collection of scientific papers, Ulyanovsk State Technical University (2016)

21. Collection of materials on the results of the project, Creation of a resource center for socially oriented non-profit organizations of the Pskov region (2015) 